\title{
THE EMPOWERMENT OF COMMUNAL AND SOCIO- CULTURAL VALUE IN PYRAMID SCHEME DISPUTE SETTLEMENT
}

\author{
Tuti Rastuti ${ }^{1}$, Utari Dewi Fatimah ${ }^{2}$, Gandhi Pharmacista ${ }^{3}$ \\ ${ }^{123}$ Law Faculty of Pasundan University \\ ${ }^{3}$ Gandhi.pharmacista@gmail.com
}

\begin{abstract}
Due to the unlawful practice of pyramid scheme business, there has been noticeable damage on communal value and living law within the affected communities. This condition becomes the source of dispute and affects the loss of trust, harmony and the damage of social and communal order. The segregated litigation process which is the most common solution could not solve the complex nature of the dispute. Therefore, there should be a new comprehensive alternative to restore both financial loss and the damage within the affected communities. The research aims to study the use of communal and socio-cultural value in the settlement of Pyramid scheme dispute, which is not only vulnerable as the modus of the scam but also as the solution for the victims. The method used is juridical empiric with juridical normative should be approach. The research shows the analysis of legal framework to solve the conflict within the community caused by pyramid scheme progressively. The research indicates that penal mediation could be the solution of the problem. The research outcomes could contribute to the alternative to settle the dispute, also to restore the social order and to restore appropriate losses and restore socio-communal culture.
\end{abstract}

\section{Keywords: Communal Value, Pyramid scheme, penal mediation}

\section{Introduction}

It is widely known that pyramid scheme has been recognized as a type of fraud in the business world. Even in the beginning of its rise in 1920s, pyramid scheme which also named as Ponzi scheme has managed to draw a big financial lost (Cantoni, 2009). It has been a consensus that this type of fraud is not sustainable and is bound to cost the involved parties an evitable loss.

Even though it has been regulated as illegal practice in many countries including in Indonesia, pyramid scheme is still spreading like a wildfire. Its growth cannot be separated from the recruitment system which relies on intrapersonal relationship, namely family, friends, neighbours and community. As the result, along with the collapse of the pyramid, the relationship of those who are involved more often become strained and the sociocultural order in question become ruined. Moreover, in many cases, it is hard to determine the mastermind of the fraud and the promotors of the lower tier of the hierarchy are being held responsible for the crime they are not aware of committing.

While the financial loss and legal measures are put forward; there is no guarantee that the communal value and interpersonal relationship between the victims and the recruiters can be fixed. More often, the sociocultural damage caused by pyramid scheme hat irreversible and is untouched by the legal system. It is also important to note that there is no overarching solution in the legal system regarding this matter that solves both informal and formal consequences of the scheme, especially in Indonesia. 
Through penal mediation, to restore the community relationship is strongly considered in order to prevent further destruction of the community values. The opportunity to gather all the involved parties allow everyone to speak up and listen, enabling them to understand the problem from different perspectives and comprehend the complex nature of pyramid scheme they are involved in. The restorative solution also has to be aligned with the litigation system in order to solve the problems caused by the pyramid scheme thoroughly and meticulously.

The article is to study the empowerment of communal and community value in settling business dispute caused by pyramid scheme.

\section{Problem Statement}

1. How do communal values influence the recruitment of investors into pyramid scheme?

2. What legal aspects inflected by the pyramid scheme?

3. How the dispute caused by pyramid scheme could be solved through penal mediation using communal value?

\section{The Importance of Research}

To bring the comprehensive solution of pyramid scheme dispute into the table, it is important to examine the matter from various perspectives. While the countermeasures of the pyramid schemes have been pursued through litigation process and the restoration of financial loss for the victims. There is no clear indication that the legal system in Indonesia also mitigate the damage of social order caused by the scam. In addition, the current studies on Pyramid Scheme Dispute Settlement has touched very little on the social and communal damage aspect of it. Hence, the study is important to look into alternative solution to deliver integrated solution to the damage of pyramid scheme; so it is not only to solve the financial loss but also to avoid further damage of the community involved.

\section{A Brief Explanation: The Pyramid Scheme}

Since its rise in 1920s (Vander Nat, 2014; Valentine, 1998) the scheme then evolves into many shapes and forms, such as direct selling, money game, and chain letter (Bosley and Knorr, 2018). In most countries, ponzi and pyramid scheme are deemed as illegal business practice, even though similar scheme as Multi-level Marketing (MLM) is yet to be considered illegal due to sales of product in the system (Shiller, 2003; Lewis, 2015 in Bosley and Knorr, 2018).

Essentially, all forms of Pyramid schemes have the same aim: to make a quick money with very little to no effort by recruiting others to join the scheme. How they lure the victims is also very similar; the new recruits would make unreasonable profit from the investment in a very short time without having no sales or real investment (Kipilimba, 2017; Valentine, 1998). Many recent cases are even harder to recognize as they disguise the scam by having products; however, the primary income still relies heavily on the recruitments of the new members or regulate the sales mainly among the members. As the result, it is impossible for the pyramid to sustain itself from collapsing (Kipilimba, 2017).

It is clear that any type of Pyramid Scheme is a form of fraudulent; so why they are still growing and even more spread out across the globe? Kipilimba (2017) suggests that not only it's because of the lack of awareness of the fraud and personal greed, there is also evidence that peer pressure also an important role for the deceived. Social network also has been found to be crucial to the growth of the system and 
exploits the existing ties of family and friends (Bosley and Knorr, 2018). The credibility of the perpetrators or promotors are amplified as personal network and connection are affiliated (Perri and Brody, 2012). Not rarely, the fraud comes from the religious leaders or using the notion of religion (Kipilimba, 2017; Perri and Brody, 2012)

The fraudulent are extremely dangerous, not only for the individual victims but also the community in general. Some of the cases even affected the economy such as the economy crises in Albania in 1997 (Jarvis, 1999) and caused riots, for instance the riot in Ireland, 2006 and in Columbia, 2008 (Kipilimba, 2017). Most often, while it may be possible to minimize the damage of the scam in terms of financial loss; the communal and social order and psychological damage among the victims are often being left out and become too broken to be fixed.

\section{Method}

The method used in this study is juridical empirical by analyzing the legal framework that can resolve conflicts caused by the practice of progressive pyramid schemes by applying convergence of legal responsibility to offerers, so as to provide the best solution to restore social and communal values and order with apply the principles of compensation for losses suffered by victims.

\section{Result And Discussion}

\section{Pyramid Scheme in the Indonesian Legal System}

Pyramid scheme business model intersects various legal aspects in the Indonesian Law, including Norm and Socio-cultural value, Economic Law, Civil Law, and Criminal Law. Explicitly, Indonesian Law No. 72014 in Article 9 prohibits the implementation of pyramid scheme in marketing products. However, nowadays the pyramid scheme has been wrapped and disguised into so much more sophisticated scheme, including investment venture, as business entity or corporation which run businesses. Nonetheless, any type of fraudulent shares almost similar characteristics that could be identified even if some of them do not claim using pyramid scheme by identifying the nature of the business (see Fig. 1).

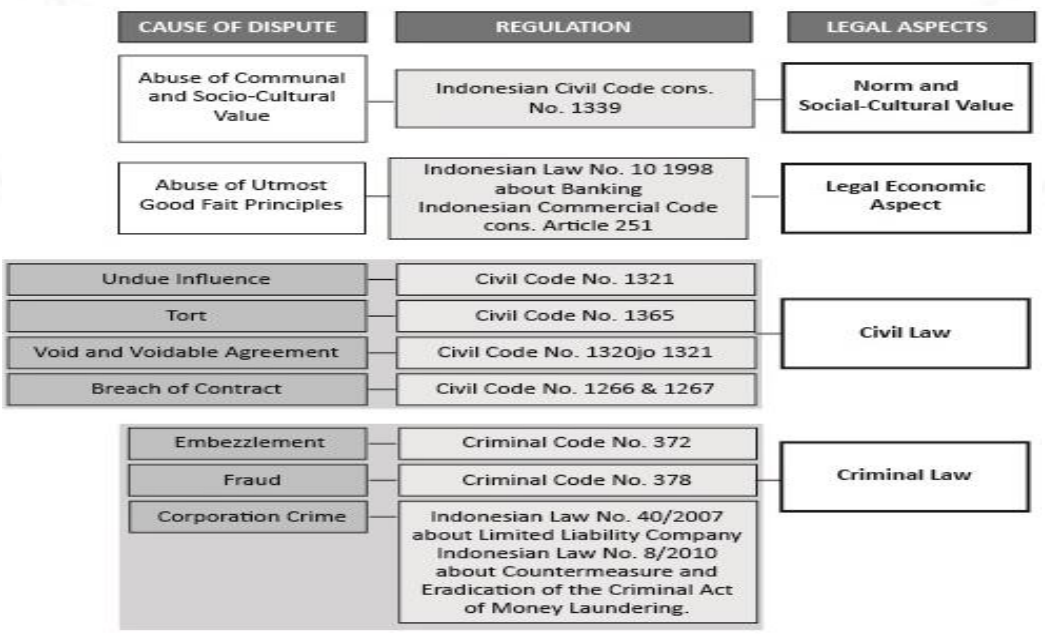

Fig. 1 Regulation of Pyramid Business Scheme in Indonesian Legal System. source: author 
Mostly, the perpetrators of Pyramid Scheme of Criminal Law shield the fraudulent nature of the business in the name of freedom of contract regulated in Indonesian Civil Code Article No. 1338 (1). However, if it is to be examined further, the freedom of contract is restricted by Indonesian Civil Code Article No. 1338 (3) about Good Faith Principles, Indonesian Civil Code Article No. 1338 about propriety principles which also stated in Indonesian Civil Code No. 1320 jo 1321 . It is clearly stated that the agreement is void if it contains errancy, coercion and fraud. As many pyramid schemes disguised themselves as an investment venture or retail venture, most of them deceit the recruits using wrong information and fabrication of evidence. For example, Virgin Gold Mining Corporation that has been identified as illegal business lure the victims using pictures of the gold mining in Dubai and the visit of the VGMC representatives to the said mining, which makes the victims convinced that the object of investment is real even though the fact it is not as seen. Consequently, it also violates Indonesian Civil Code Article No. 1365 about Tort, in which the consequences are regulated in Indonesian Civil Code Article No. 1335 about the legal consequences of the agreement that based on fraud. It is also become a breach of contract as the information provided in the negotiation is false, which is regulated in the Indonesian Civil Law Article No. 1266 \& 1267 and violate utmost good faith principles which regulated in Code of Commerce Article No. 251.

Moreover, freedom of contract is also confined by the utmost good faith principles as regulated in Indonesian Civil Law Article No. 1338 (3) which is also supported by Indonesian Civil Law Cons. Article No. 1339 that that requires the parties involved in the agreement to comply with fairness principle, in regards of lawful norm, and not to be contradicting with morality and public interest. For example, the case of First Travel that deceived people in the name of religious belief for Muslims who want to go to Hajj and Umrah. Taking religion as a tool to deceive people is extremely disrespectful and taboo, especially for devout believers; which, in this case are Indonesian Muslims who invest their money in the name of God. Therefore, not only it violates the civil code and criminal code, but also do not comply with utmost good faith, morality and public interest.

One case in particular, shows that the pyramid schemes such VGMC has also exploited undue influence to recruit people which against the Indonesian Civil Law No. 1321. One respondent who was the victim of VGMC scam stated that the promotors lured her into the scheme because they knew that her husband has resigned and was unemployed at that moment; which made her in desperate need of money. As the promotors guaranteed a $10 \%$ return each month, and she knows the offeror very closely; she unfortunately fell into the trap. In this case, the offeror uses the influence of economy level and trust of the victims and abuses the condition.

In terms of trading, pyramid scheme businesses solely collect money from the subjects. It clearly violates a number of Banking Regulation as the only institution that has the legal authority to collect fund from the civilians are banking or non-banking organizations that are listed and approved by the Financial Service Authority (OJK). It is explicitly regulated under the Indonesian Law No. 101998 about Banking. The violation of the utmost good faith principles also against Indonesian 
Commercial Code Cons. No. 251 which makes the pyramid scheme falls into illegal category.

In addition, these corporations also are guilty of many crime; from fraud by spreading false information, embezzlement by taking the recruits' money for their own interest and even as far as doing money laundering. For instance, according to the Case No 2127K/Pid.Sus/2016 Wondermind Ltd has been prosecuted for multiple indictments, including Indonesian Law No.8. 1998 Article No.46 (1) about banking, Indonesian Law No.8.2010 about money laundering, and Criminal Code Article No. 372 and 378 for fraud and embezzlement. Likewise, the responsibilities of the perpetrators; even if the crime was done through corporation; still fall into the individuals who commit the crime even by using their personal assets as regulated in Indonesian Law No. 402007 about Limited Liability Company (Rastuti, 2015).

\section{Sociocultural and communal Value as the Double-Edged Sword}

Almost all of pyramid scheme businesses target specific group of people, not only it is easier to use the pre-existing condition of a community; the communal values that has been emblemed within also to play the role in convincing the people to join the system. Bernie Madoff (Frank, 2012 in Bosley and Knorr, 2018), Seng Tan (Perri and Brody, 2012), and Abraham Kennard (Fairfax, 2002 in Perri and Brody, 2012) are among many who use communal value in fooling people into pyramid schemes; specifically by influencing the leader first before coming to the crowd. It is also commonly known as affinity fraud. In this context, the communal values in the question include the sense of community, in which Mc Millan
(1996) describes as: a spirit of belonging together, a feeling that there is an authority structure that can be trusted, an awareness that trade, and mutual benefit come from being together, and a spirit that comes from shared experiences that are preserved as art."

Perri and Brody (2012) describes affinity fraud as the fraud that exploits network/ affiliation of the victims and even yet targeting exclusive group to avoid notice of outsiders. The method could be altered into various different forms, it could be religious meetings or empowering program for specific ethnic groups. Frank (2012), as described in Bosley and Knorr (2018), points out that the victims contribute to the distribution and influence of the con artist. The consequences could be profoundly negative as the trust, the sense of community and the sense of kinship that become the core of the community is severed. Unfortunately, the affected communities would keep the problem within themselves as try to resolve it independently and reluctant to let the problem be publicly known. As Austin (2004) and Fairfax (2001) in Perri and Brody (2012) stated, the factors could be inexperience, embarrassment, guilt, exclusivity and the denial that such fraud could happen. Although, the unwillingness to recognize the pyramid scheme in deeper level contributes to the problem within exclusive society; Kipilimba (2017) in particular mentions that the people in Tanzania refuse to identify themselves being involved in pyramid scheme even though they do not have enough knowledge about pyramid scheme. It shows that even though they are not well informed, they are commonly aware of the negative association it carries. Such notion contributes to the denial in acknowledging the fraud within the community as well as unwillingness to 
educate oneself to prevent the fraud from sprouting and spreading.

Not rarely, education and economic factors also come into play. Kipilimba (2017) states in his study that some areas are more vulnerable to scam because the perpetrator chooses to slip into these aspirations, accompanied by a wellconnected social network, are expected to be positively related to income-related fraud. In Indonesia; housewives and economically-vulnerable groups are common to be the victims of the pyramid scheme (Manurung, 2013), particularly in well-organized society and groups. The perpetrators would not only exploit the existing network, but also the incapability of the victims in generating income; whether it is because the limited time, other responsibilities that need to be fulfilled, or simply the need of easy money. In some cases, however; the fraud happens within well-educated and wealthy groups. Most often; the trust comes due to the intense marketing or the use of well-known public figure and wellrespected professionals as the representatives (Supreme Court Decree No. 434 K/PID/2015). The case of Wondermind Ltd. (Case No. 340/Pid.Sus/2015/PN.JAP Jo.) for example; exploiting the profession of one of the initiators as a university lecturer to convince people of the legitimacy of the business; while the case of VSI (Duta and Tobing, 2014) uses well-known public figure as the ambassador and the founder.

As the fraud often targets specific and exclusive group; religious groups also become extremely vulnerable to the scam. Usually, religious groups are motivated by goodwill and religious motives. Once the leader of the group or a prominent figure become influenced, the followers likely not fall behind. Austin (2004) argues that the recruiting techniques are tailored to fit the specific groups. In cases with religious motives, the scammers impose a false perception that the scheme they promote not only for the goodwill but also follow God's order by infusing religious text, prayers, and bible.

Internationally; Mormon, Seventh-day Adventist, Baptist, Amish and fundamentalist Christian communities are among many whom suffered affinity fraud (Perri and Brody, 2012) while in Indonesia, the case first travel (The Jakarta Post, 2017) and the case Abu Tour (Astuti, 2018) are among the instances in which the scammers exploited the motive of Hajj and Umrah to lure the victims into the scheme. As Hajj and Umrah are among Islamic acts of devotion, the perpetrators convince clients and potential investors to invest in the business as well as doing the God's will by helping the pilgrims reach the intended destination to perform Hajj and Umrah. Nonetheless, it is clear affinity fraud using pyramid scheme is not something new and uncommon, particularly in Indonesia. While there has been a consensus that the scheme itself is a fraud; it is hard to overcome when the public refuse to acknowledge that they may be involved in the said scheme, especially when it comes to exclusive community groups. Not only it has profound consequences in terms of financial loss and legal act; it also becomes enormous threat to the community and the communal value shared among the members. there has to be emphasized that in a pyramid scheme; the promotors in the middle of the pyramid take the role both as the perpetrator and the victim, thus make it harder to determine whether one is eligible to cover another's financial loss. Due to this, some people may resent other community members, colleagues or friends and family. The trust, sense of community and kinship become hard to restore once it has been damaged. 


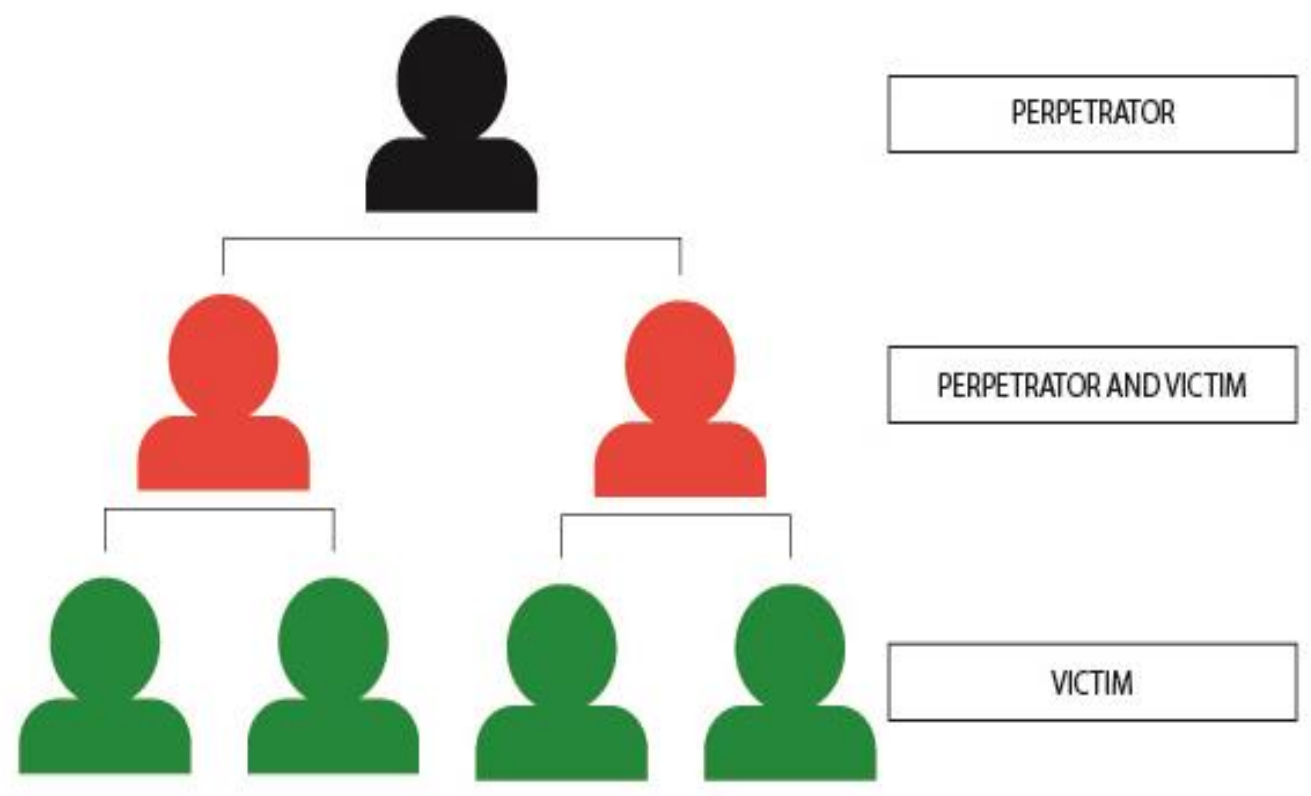

Fig. 2 Illustration of Pyramid scheme source: author

However, while pre-existing network within the communities is vulnerable to affinity fraud; the same communal value also could be the tool to glue the community back together. After all, the trust, the sense of community and kinship was not built overnight and has been based on the extensive interaction and relationship within the community. In some cases, many of the victims refuse to listen and instead blame each other for the loss they have suffered, but some do not realize that other parties also suffer similar problem. For example, victims of VGMC that have affiliation to a University in Bandung, Indonesia may be aware that the case has been legally proceeded however some of them may be not aware of the overall nature of the fraud within the community. As the result, some of the community members resent each other, especially those who suffer the most financial loss. It is not the only case which shows similar situation. That being said, the damage on community and communal values could be overcome if only there is mutual understanding between parties, in which the community come together to seek a fair and best solution to restore the loss the community suffered.

The role of community leader in this sense is crucial to bridge the communication within the community; however, it may be difficult without neutral party involved in the process. That is why negotiation which involve the affected community members become important to minimize the consequences that both the community and its members suffered. Penal mediation; which to be discussed further; is one of the solution to cover the psychological and communal consequences of the fraud; along with legal action and other measures in a convergence model. This way, communal values are to be double edged sword; even though they are vulnerable to the fraud, they also can be used to glue the community back together.

Penal Mediation as a Part of the Convergence Model in the Settlement of Pyramid Scheme Dispute 


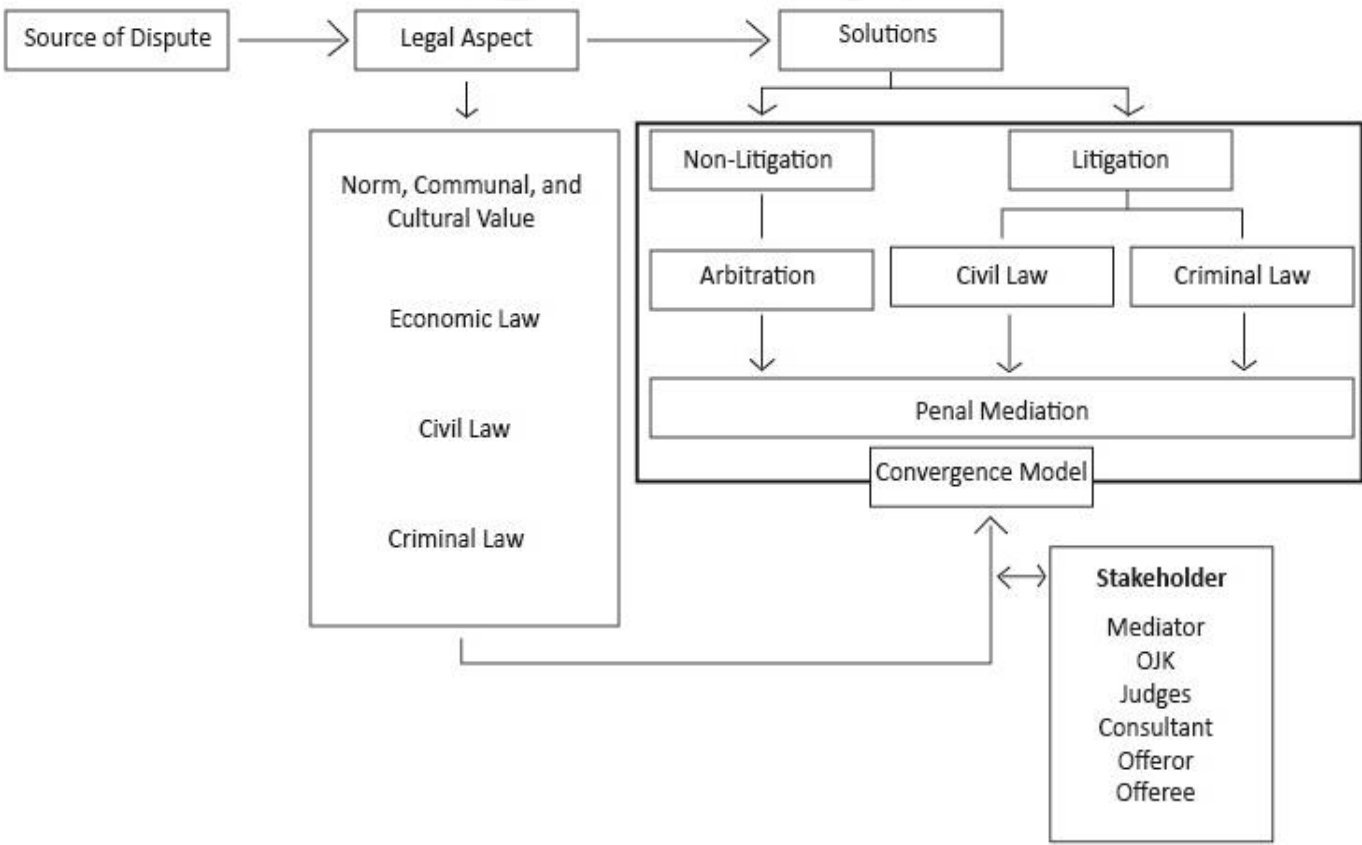

Fig. 3 Convergence Model Framework source: author

The role of community leader in this context is extremely important to bridge the communication within the community. However, it may be hard to achieve middle ground if there is no neutral party involved in the process. That is why, negotiation which involves the community member whom being affected becomes important to minimize the consequences that fall upon the community and its members. Penal Mediation, which will be explained further; is a solution to cover the consequences of psychological and communal aspect in the scam, along with other legal measures and other methods in the convergence model.

Up until now, the restoration of loss in pyramid scheme is heavily reliant on litigation. However, going through litigation process may be less flexible in the decision making, especially to restore the loss of the pyramid scheme victims. Even though litigation process is based on the regulation related to the matter; the outcomes may be far from satisfactory as it allows smaller room for negotiation. For example, the Case of Pandawa (Supreme Court Decree No. 16/Pdt/G/2013/PN.PO, Provincial Court Decree No. 16/Pdt/G/2013/PN.PO) ensues in disappointing result for the victims. The personal asset that has been detained from Pandawa leaders was confiscated by the State instead of being used for recovering the victims' financial loss. The decision was made based on the State Banking Regulation, which made it impossible for the victims to file in an appeal. It shows that relying solely on litigation process without a comprehensive solution may not provide the best solution for all. 
To mitigate psychological and communal aspect of negative impacts caused by pyramid scheme; Penal Mediation could be a ground-breaking solution to integrate the settlement of the dispute. Penal mediation itself in this context is a part of comprehensive solution that combine various method using convergence model as litigation process has been proved not to be effective. According to The Council of Europe (in Lhuilleir, 2007), penal mediation could be described as "any process whereby the victim and the offender are enabled, if they freely consent, to participate actively in the resolution of matters arising from the crime through the help of an impartial third party (mediator)". Flora (2015) argues that penal mediation could be assessed from various perspectives including philosophical, sociological and legal aspect.

In the philosophical perspective existence penal mediation principle applied solution containing "a win-win" and not end up with a situation of "loselose" (lost-lost) or "win-lose" (win-lost) as to achieve justice to the achievement of the formal justice through the legal process (law enforcement process)"

Penal mediation is also a form of restorative justice and a form of alternative dispute resolution (ADR) outside the court (Flora, 2015). According to Indonesian Law No. 30 1999 Clause 1 (10), ADR is: The Institution of dispute settlement or conflict through the procedure that has been agreed by the involved parties, which is the settlement outside the court by consultation, negotiation, mediation, conciliation, and expert judgement."

In other countries, penal mediation has been known to be an alternative solution in various cases (Burssens,
2012). In Indonesia, penal mediation has not yet been acknowledged by the formal legal system; however, it has been used to solve various cases both in the civic cases and criminal cases outside the court (Flora, 2015).

According to Mannozzi (2011), in penal mediation, there are two obvious sides which are the perpetrator and the victim. As the name suggests, in the process, the role of mediator is extremely important to bring the resolution of the conflict to the table. It is also said that: Dialectical movement is required which leads to 'knowledge' and which, in the particular case of penal mediation, brings the offender to an understanding of the motives, feelings and the need for compensation for the victim. Likewise, the victim must gain awareness of the personal, family and social condition of the offender, not to mention the reasons behind the crime."

Penal Mediation is important to create mutual understanding between the victims and the offenders to reach common-ground. In the fraudulent like Pyramid scheme, often the offenders are also the victim of other recruiters, which makes the settlement even more difficult as the main mastermind often originated from outside the country or is difficult to be prosecuted for various reason. By resolving it through penal mediation, it would allows both perpetrators and victims to hear and understand the circumstances from both sides and to fully understand the complex nature of the scheme. Only after the common ground has been reached, the settlement to restore the loss could be more easily achievable. Therefore, the settlement of the dispute should be easier if all the parties involved understand the matter from different perspectives to reach agreement all while maintaining the social and communal order. 
However, although having a huge contribution, the penal mediation is still a part of a bigger picture (see Fig. 3). The comprehensive solution should be proceeded both through litigation and non-litigation processes. Through nonlitigation process, the negotiation should be proceeded through arbitration which allows both parties to reach into agreement. During the litigation process; it is clear that the dispute should be reviewed through criminal law, civil law, and other legal regulations. However, before bringing it to the table; the court along with other authorities should allow negotiation to be pursued first as a part of litigation process. The negotiation process should also involve the judges; the Financial Service Authority (OJK) as the institution which responsible to supervise the corporation (if it involves corporation) and to give sanction and consequences accordingly; consultants as legal advisor for both the victims and perpetrators; and the most importantly, the mediator who preferably is someone that is well respected in the affected community (e.g. community leader). This way, even though there is still a high possibility that the victims' loss could not be compensated fully; there is still a responsibility that has been fulfilled by the perpetrators. If it involves corporation, the convergence model and penal mediation open the possibility to restore the loss (especially financial loss) using the personal asset of the board members or the higher ups of the corporation.

However, it should be acknowledged that to reach the best solution for all may be time consuming if it is not done responsibly, for example if the mediator is biased or the authority does not provide continuous process until the problem is fully resolved. Otherwise, it may cut down a lengthy process in the court if the agreement has been reached in the penal mediation. Also, it is impossible to reach the common ground in very little meeting; which means it requires continuous process that obligate all parties to fully invest their time and thought in the process. It may be difficult to fix the broken ties and network if one community is affected; because it has been built throughout long period of time and excessive interaction. However, as Spencer and Hardy (2014) claims, one step to solve a broken relationship is to listen and understand the interests of all parties, otherwise it would be a futile attempt in a negotiation. It may take a day or a year to fully recover the social disorder; but it is not impossible to do so. That way, it is only fair for all parties to be listened and for their problem and circumstances to be respected by hearing their problem in depth; which not only allows to compensate the financial loss but also to provide a fair solution for all.

\section{Conclusion}

1. The solution of the dispute caused by pyramid scheme by using conventional method through litigation process has been evaluated as not successful in settling the financial loss and other consequences such as the disruption of living law values. Legally, the perpetrators may usually be prosecuted, however there is little to none measure in restoring the financial loss of the victims.

2. The complexity of pyramid scheme dispute could be examined from criminal law, civil law, and economic law aspect, along with norm and values of living law. Thus, the settlement of dispute should be observed and be done from multi-aspect approach, including communal and sociocultural value. One of the solutions for psychological and communal 
consequences of the scam is to apply convergence model as the legal responsibility. Convergence model applies few legal aspects that occur from pyramid scheme complexity, including using living law within the community to achieve the best and comprehensive solution. Through this measure, communal values could be a double-edged sword; which even though they are vulnerable to be misused as scam tool; they also could be used to glue the community back together.

3. Pedal Mediation could be applied to settle pyramid scheme dispute as a part of the restoration of communal and socio-cultural value within the community to recover social and communal damage. The research found comprehensive solution to restore financial loss and other damage caused by pyramid scheme; which not only solves the problem but also prevents further damage.

\section{Acknowledgement}

This research was supported by Kemenristek Dikti which has the funded the applied product grant (2017) and the national research strategic (2018). We thank our collegues from Pasundan University, who provided insight and expertise that greatly assisted the research, although they may not agree with all of the interpretations/ conclusions of this paper.

We thank to Mrs. Nia Kania Winayati, S.H., M.H for assistance with particular technique, methodology and for comments that greatly improved the manuscript. We would also like to show our gratitude to Dr. Anthon F. Susanto, S.H., M.Hum for contributing as reviewer of research and book making as research product, we thank Mr. Tjandra Nyata for research review from OJK (Otoritas Jasa Keuangan) and Ana
Ramdani Sari for contributing in literature research.

Finally, we are very grateful to God almighty who has given us strength and health in completing this journal, and we do not forget to thank the parties that we can not mention one by one, as well as our institution in, and help/ contribute thoughts in the process of preparing this jurnal.

\section{References}

Astuti, B. W. (2016). Mfloraulti ethical problems dalam bisnis multi level marketing (Studi Kasus Akun Facebook WW). Cakrawala, 5(2).

Austin, D. E. (2004). In god we trust: the cultural and social impact of affinity fraud in the african american church. U. Md. LJ Race, Religion, Gender \& Class, 4, 365.

Burssens, D. (2012). Penal mediation in Belgium. Insights on the basis of registered data.

Cantoni, C. J., 2009. A brief history of Ponzi schemes. Journal of American Physicians and Surgeons, 14(1), 24-25.

Case No. 2127K/Pid.Sus/2016

Case No. 340/Pid.Sus/2015/PN.JAP Jo.

Court orders First Travel to repay customers. (2017, August 22). Retrieved from http://www.thejakartapost.com/ne ws/2017/08/22/court-orders-firsttravel-to-repay-customers.html

Duta, D.K. and Tobing, Mona. (2014, May 2). Bisnis VSI milik yusuf mansur dinilai ilegal. Retrieved from

https://ekonomi.kompas.com/read/ 2014/05/02/1536262/Bisnis.VSI.M ilik.Yusuf.Mansur.Dinilai.Ilegal

Filbert, R. (2015, July 3). Mengenal bisnis MLM. Retrieved from https://ekonomi.kompas.com/read /2015/07/03/130000726/Mengena 1.Bisnis.MLM 
Flora, HS. (2015). Penal mediation as an alternative model of restorative justice in the criminal justice system of children, International Journal of Business, Economics and Law, 6(4) 6-10

Frank, S. P, Richard G. B. (2012) "The optics of fraud: affiliations that enhance offender credibility", Journal of Financial Crime, Vol. 19 Issue: 4, pp.355-370

Galvin, W.F. (2014). Secretary galvin warns of illegal pyramid schemes disguised as multi-level marketing businesses (MLMs). Retrieved from

https://www.sec.state.ma.us/sct/sc tpyramid/pyramididx.htm

Indonesian Civil Law No. 1226\&1267

Indonesian Civil Code No. 1320jo 1321

Indonesian Civil Code No. 1335

Indonesian Civil Code No. 1338 (1)

Indonesian Civil Code No. 1365 about

Tort

Indonesian Civil Law No. 1338 (3)

Indonesian Civil Law Cons. No. 1339

Indonesian Civil Law No. 3121

Indonesian Commercial Code Cons. No. 251

Indonesian Criminal Code No. 372 and 378

Indonesian Law No. 72014

Indonesian Law No.8 2010 Article No.46 (1)

Indonesian Law No. 101998 about Banking

Indonesian Law No. 301999 Clause 1 (10)

Indonesian Law No. 402007

Jarvis, M. C. J. (1999). The rise and fall of the pyramid schemes in Albania. International Monetary Fund.

Kipilimba, T. F. (2017). Effect of Pyramid Schemes to the Economy of the Country - Case of Tanzania, International Journal of Humanities and Management Sciences (IJHMS) Volume 5, Issue 1. ISSN 2320-4044
Lhuillier, J. (2007). The quality of penal mediation in Europe. Strasbourg, Council of Europe, European Commission for the Efficiency of Justice, Working Group on Mediation.

Mannozzi, G. (2011). From the 'Sword' to dialogue: towards a 'dialectic' basis for penal mediation in Weitekamp, E. G., \& Kerner, H. J., (Eds.). (2012). Restorative justice: theoretical foundations. Routledge.

Manurung, FN. (2013). Perempuan dalam sistem jaringan multi-level marketing oriflame cabang yogyakarta. Retrieved from http://e-journal.uajy.ac.id/3262/

McMillan, D. W. (1996). Sense of community. Journal Of Community Psychology, 24(4), 315-325.

Özbek, M. (2012). The principles and procedure of penal mediation in turkish criminal procedure law. Ankara Law Review, 8(2), 153220

Provincial Court Decree No. 16/Pdt/G/2013/PN.PO

Rastuti, T. (2015). Seluk beluk perusahaan dan hukum perusahaan. Bandung : Gramedia Pustaka Utama.

Stacie, B, Maggie, K. (2018). "Pyramids, ponzis and fraud prevention: lessons from a case study", Journal of Financial Crime, Vol. 25 Issue: 1, pp.81-94, https://doi.org/10.1108/JFC-102016-0062 Shiller, 2003

Spencer, D., \& Hardy, S. (2014). Dispute resolution in Australia: cases, commentary and materials. Thomson Reuters

Supreme Court Decree No. 16/Pdt/G/2013/PN.PO

Supreme Court Decree No. 434 $\mathrm{K} / \mathrm{PID} / 2015$

Tio,\& Nurjanah, R. (2017, August 2017). First Travel dan Deretan 
Bisnis Abal-Abal Berskema Ponzi di Indonesia. Retrieved from https://kumparan.com/@kumpara nnews/deretan-bisnis-abal-abalberskema-ponzi-di-indonesia

Valentine, D. A. (1998). Prepared statement of Debra A. Valentine, General Counsel for the US Federal Trade Commission on 'Pyramid Schemes' presented at the International Monetary Fund's seminar on current legal issues affecting central banks, Washington, DC, May 13, 1998. Bosley and Knorr, 2018
Vander Nat, P. J., \& Keep, W. W. (2002). Marketing fraud: An approach for differentiating multilevel marketing from pyramid schemes. Journal of Public Policy \& Marketing, 21(1), 139-151.

W. Keep, W., \& J. Vander Nat, P. (2014). Multilevel marketing and pyramid schemes in the United States: An historical analysis. Journal of Historical Research in Marketing, 6(2), 188-210. 